\title{
Review
}

\section{Contesting conformity: Democracy and the paradox of political belonging}

\author{
Jennie Ikuta \\ Oxford University Press, New York, 2020, x + 192pp., \\ ISBN: 978-0190087845
}

Contemporary Political Theory (2022) 21, S67-S70. https://doi.org/10.1057/s41296020-00455-9; published online 27 November 2020

American politics unabashedly valorizes nonconformity, celebrating the rare individual who challenges prevailing social and political norms, cultivates their inner voice, and combats longstanding injustices and inequalities. Individuality, novelty, and rupture, we assume, are fundamentally good for democratic politics. Or as Jennie Ikuta puts it in her provocative new book on nonconformity, 'we conform to the value of nonconformity' (p. 11). But is nonconformity inherently good for democratic politics? To what extent does nonconformity advance or threaten democratic ideals and institutions?

In Contesting Conformity: Democracy and the Paradox of Political Belonging, Ikuta argues that nonconformity is not necessarily democratic, but can either further or threaten democratic values. In this refreshingly clear and deeply provocative book, Ikuta aims to 'move us beyond the unconditional valorization of nonconformity in contemporary American rhetoric', showing that the concept has been invoked toward radically opposing political ends. On the one hand, nonconformity resists racial injustice and religious persecution, and on the other, it emboldens alt-right leaders and organizations (p. 153). Nonconformity must be guided by some other orienting principle, implying that it matters to what we conform - or refuse to conform. For Ikuta, nonconformity is worth celebrating to the extent that it furthers the democratic value of relational equality which she defines as 'sharing power over the terms of collective existence' and 'relating to one another as equals' (p. 19). Toward this end, Ikuta engages with three theorists (or critics, really) of conformity - Alexis de Tocqueville, John Stuart Mill, and Friedrich Nietzsche - to show how compliance implies a relational or individual loss of independence, autonomy, and creativity. The three substantive chapters of the book contribute to longstanding interpretive debates on these canonical figures to clarify the potential impact of nonconformity on democratic politics. By reconstructing their critiques of conformity, Ikuta illuminates the potential advantages - and overlooked dangers - of nonconformity.

(C) 2020 Springer Nature Limited. 1470-8914 Contemporary Political Theory Vol. 21, S2, S67-S70 
Tocqueville and Mill, Ikuta suggests, help us think about the advantages of nonconformity in democratic politics, in part, by centering the disadvantages of conformity. For Tocqueville, conformity implies intellectual stagnation and the perpetuation of domination. For Mill, conformity corrodes the possibility of an authentic, fully realized individual. Both figures, however, suggest that nonconformity can serve broader democratic ideals, fostering individuality and judgment in democratic citizens, thwarting intellectual complacency, and combatting injustice in social and political life.

Tocqueville, of course, offers a now-familiar critique of democracy as fostering intellectual docility and laziness, culminating in a widespread withdrawal from political life and the inauguration of soft despotism. Dissenters are met with severe social ostracism, 'a kind of social death', in democracies for expressing heterodox points of view (p. 39). Democratic citizens reasonably conform to majoritarian norms since they are incentivized to conceal their differences. For Tocqueville, one of the inevitable consequences of conformity is a false sense of public unanimity. The lack of critical engagement in public discourse is not demonstrative of consensus, but suppression; without public support, dissenters will not freely express heterodox positions, creating a misleading sense of uniformity in society. Commentators have traced this practice of conformity to authoritarian and persecutory conditions, from Tim Kuran's work on 'preference falsification' in authoritarian regimes to my own work on hypocritical conformity and religious dissimulation in early modern Europe. Quite understandably, religious and political dissenters willingly engage in false professions of religious conviction or political allegiance to evade expulsion, imprisonment, or violent death. Individuals are free to express a dissenting point of view in democracies, but public opinion (rather than an oppressive state) coerces citizens into conformity.

Tocqueville's solution to this problem is the cultivation of 'the conditions under which the freedom to dissent flourishes' (p. 54). The very possibility of nonconformity, oddly enough, hinges on widespread support for heterodox points of view in democracies, implying broader 'social support for opinions at odds with the ruling power' (p. 34). But to what extent do dissenters need support to challenge convention? Are there some individuals who defy convention without social support? And if not, what kind and degree of social support is necessary? Does this support need to validate the specific point of view or can it be a more ambivalent toleration of all dissent? Is it enough if this social support comes from a narrow coalition of citizens? What if others condemn the view publicly? And finally, to what extent does our near-fervent obsession with the rare, spirited individual, unwilling to conform to injustice or convention, obscure the social and political background often supporting the individual? Tocqueville's suggestion that dissenters need social support to realize freedom raises questions about the nature of that support and the relationship between individual actors and the broader social and political movements and contexts in which they act. 
Like Tocqueville, Mill is deeply concerned about the impact of conformity on democratic citizens, but he focuses specifically on the psychological impact of conformity on the individual. For Mill, conformity does not merely 'suppres[s] difference', but 'entails a deficient form of ethical selfhood marked by hypocrisy, a lack of self-direction, and superficiality' (p. 71). Individuals tend to conform, Mill acknowledges, given the 'moral disapprobation' that they face for dissenting, and this conformity breeds hypocrisy in democratic citizens. The pressures of conformity 'foreclose the possibility of living lives that are distinctly [our] own', leading to a kind of 'internal tyranny' (pp. 70-71). Hypocrisy, by which Ikuta means a significant 'disjunction between what individuals say and what they feel and do', poses a significant challenge for democratic politics not merely because it requires an invasive, psychologically damaging refutation of the individual's authentic beliefs but because it also corrodes the capacity for judgment in democratic citizens (p. 93). Conformity is dangerous, not merely because it makes us unreflective, but also because it makes us hypocrites. Ikuta emphasizes this psychological intuition in Mill's critique of conformity, but even Tocqueville seems to recognize the psychic dimension of conformity, echoing Jean-Jacques Rousseau's Second Discourse in his suggestion that modernity 'disfigures the soul' (p. 40). For both Tocqueville and Mill, nonconformity advances democratic values by making citizens intellectually independent, socially engaged, and politically judicious.

In stark contrast to Tocqueville and Mill, Nietzsche shows us that there are 'nondemocratic variants' of nonconformity (p. 19). Nietzsche's celebration of individuality and creativity in terms of the expression of will to power and value-creation help us see, quite clearly, that nonconformity is not necessarily democratic, but can be enlisted toward domination and an elitist vision of politics. For Nietzsche, 'anything that constrains creativity - including democracy - must be rejected' (p. 113). The 'creative individual' views himself as the 'ultimate source of authority', rejecting the majoritarian commitment to the self-determination of the people (p. 130). While Ikuta does not share Nietzsche's hostility to democracy, the book centers on Nietzsche to show that nonconformity can be fundamentally exclusionary and domineering. Nietzsche's sharp insight into nonconformity goes even further than Ikuta's acknowledgment that the rhetoric of nonconformity has been recently invoked to advance alt-right politics, implying a discerning recognition that conformity is fundamentally antagonistic to creativity.

Nietzsche's abhorrence of conformity left me wondering if the valorization of nonconformity in American politics is ultimately related to our commitment to democratic values or reflects longstanding ambivalence or even hostility to democratic principles. We encourage individuals to think for themselves rather than follow the masses, but this advice arguably implies an underlying skepticism toward the multitude. Individuals must cultivate their own perspective, in part, because the masses are presumably pedestrian, uncritical, or oppressive. In one of the many clichés lauding nonconformity, we challenge young people to think for themselves and resist peer pressure, asking 'if all of your friends jumped off a cliff, would you!?'

(C) 2020 Springer Nature Limited. 1470-8914 Contemporary Political Theory $\quad$ Vol. 21, S2, S67-S70 $\quad$ S69 
In addition to encouraging individuals to think critically, this platitude implies an underlying cynicism about the decision-making skills of one's peers. They are, after all, jumping off of cliffs. This disdain for majoritarian tendencies and distrust of collective judgment echoes influential critiques of democracy throughout Western political thought. Perhaps American rhetoric celebrates nonconformity not in spite of its ambivalent relationship to democracy, but because of a deeper hostility to democracy. I applaud Ikuta's efforts to show that conformity has a more complicated relationship to democracy through reframing Tocqueville and Mill as critics of conformity, but I was ultimately most persuaded by Nietzsche's antidemocratic position on conformity.

In her conclusion, Ikuta suggests that nonconformity should be promoted to the extent that it advances relational equality. In particular, democracies should cultivate 'dispositions' which help individuals 'relate to one another as equals' (p. 21). The political project of 'relational equality', Ikuta suggests, 'demand[s] collective reasoning and judgment', but this broad endorsement of a democratic and egalitarian vision of politics raises several questions about democratic character and processes. What dispositions should democratic citizens cultivate to realize relational equality? Which democratic and public institutions are responsible for fostering them? And finally, what does it mean to cultivate collective - rather than individual - judgment? In arguing that 'nonconformity cannot be boundless, for democracy binds it', Ikuta gestures toward the ambitions and costs of democracy, themes which I anticipate she will examine in her future work with as much clarity and sophistication as she brings to the theme of nonconformity in this book (p. 163). Contesting Conformity is a deeply engaging work of political theory that challenges us to reconsider our longstanding commitment to nonconformity, reminds us that not all good things go together, and invites us to reflect on what it means for democratic citizens to see themselves as equals.

\section{References}

Gais, A. (2020) The politics of hypocrisy: Baruch Spinoza and Pierre Bayle on hypocritical conformity. Political Theory 48(5): 588-614.

Kuran, T. (1995) Private truth, public lies. Cambridge, MA: Harvard University Press.

Publisher's Note Springer Nature remains neutral with regard to jurisdictional claims in published maps and institutional affiliations.

Amy Gais

Washington University in St. Louis, St. Louis, MO 63108, USA amy.gais@wustl.edu 